American Journal of Pharmaceutical Education 2016; 80 (7) Article 112.

\title{
VIEWPOINT
}

\section{The Influence of Interim Deans: More Than Keeping the Ship Afloat and Warming the Captain's Seat}

\author{
Cynthia J. Boyle, PharmD, BSPharm, ${ }^{\text {a }}$ Renae Chesnut, EdD, MBA, BSPharm, ${ }^{b}$ \\ Michael D. Hogue, PharmD, ${ }^{c}$ David P. Zgarrick, PhD ${ }^{\mathrm{d}}$ \\ ${ }^{a}$ University of Maryland Eastern Shore School of Pharmacy and Health Professions, Princess Anne, Maryland \\ ${ }^{\mathrm{b}}$ Drake University College of Pharmacy \& Health Sciences, Des Moines, Iowa \\ ${ }^{c}$ Samford University McWhorter School of Pharmacy, Birmingham, Alabama \\ ${ }^{\mathrm{d}}$ Northeastern University School of Pharmacy Bouvé College of Health Sciences, Boston, Massachusetts
}

Transitions are inevitable in academia, but changes in leadership personnel seem to have increased over the past several years. Participants at the 2016 AACP Interim Meeting learned that CEO dean positions are open in more than 20 of 135 colleges and schools of pharmacy. While this number seems significant, it speaks to the loss of established leadership from long-serving, dynamic deans as they retire or move into other positions within their universities. In addition, the expansion of satellite campuses and new schools of pharmacy has fueled a shift of academic leaders from established schools to newer programs. Furthermore, some deanships are open because the initial appointment was not a good fit. Regardless of the reason for the departure, when a school's dean chooses to leave, the institution is faced with the critical decision of who should be appointed as the interim dean.

Although a few institutions are able fill the dean position without an interim dean, most schools elect to appoint one. When an interim dean is named for a school, there are key considerations for the institution and the individual selected. As individuals who have served in a variety of interim dean positions, we wanted to share our perspectives on the role of interim dean and how the position can best be utilized until a permanent dean is appointed. While this Viewpoint focuses on the position of interim dean, many of the comments can be applied to other interim roles and can broaden the perspectives on preparation strategies and career planning of pharmacy deans. ${ }^{1}$

While all schools of pharmacy will find themselves searching for a dean at some point, the number of open positions indicates that more institutions are dealing with the challenge of a dean search, which begins with determining who should serve as the interim dean. That urgent decision is based on what qualities are needed for the interim dean, what needs to be accomplished during the interim appointment, and whether it is in the best interest of the institution for the proposed interim dean to vacate his or her current position.

Many may consider the appointment of an interim dean as a logical, progressive decision, perhaps with an assistant or associate dean stepping into the role. However, this may compromise operations. For example, an associate dean of academic affairs in the midst of leading a curricular revision, or an assistant dean for research leading an NIH grant renewal, may not be the best choice even though such individuals are likely to have tremendous leadership experience and skill. Department chairs, who tend to have strong personnel management skills, as well as budget oversight responsibility, may seem like logical choices. However, the interim dean appointment often vacates an existing role for the period of the interim appointment, creating the need for other interim appointments, which can lead to further disruption in administrative functions.

The length of the interim appointment is often uncertain because of the time needed to recruit, interview, and hire the dean, as well as the time for the new dean to transition commitments at his or her current institution. This uncertainty may worsen in the event that the number of open positions grows. Despite meaningful leadership development programs such as the AACP Academic Leadership Fellows Program (ALFP), a relatively small pool that represents the most highly qualified individuals will be courted by multiple institutions at any one time.

In the authors' experience, an institution should generally plan for at least a one-year interim dean appointment. Thus, the institution will need to consider the challenges the school will face within the ensuing 12 to 18 months prior to appointing an interim dean. It may be tempting for the institution to delay initiatives, strategic plans, etc., until a new dean arrives; however, that is not always optimal for the program. Thus, the institution must balance moving goals forward while avoiding commitments 


\section{American Journal of Pharmaceutical Education 2016; 80 (7) Article 112.}

that create additional challenges for a new dean. This particularly may be the case for interim deans who plan to return to their previous position following their service as interim dean. They may not feel the need to make changes, and they may not have the desire to "rock the boat."

Additionally, the institution must carefully consider applicants for the interim position. While the institution may benefit from the leadership the interim dean brings, the potential downside is if the interim applies but is not selected to become the dean. In this circumstance, the institution would need to determine how to continue to engage the interim dean in his/her role as a faculty member and/or administrator after the interim appointment concludes.

We suggest these characteristics and attributes to identify an interim dean: (1) An individual who is universally respected by existing faculty members and who has demonstrated leadership within the school. This does not necessarily need to be a current academic leader, but could be someone who previously served in an administrative position and continues to serve on the faculty; (2) An individual whose appointment will result in the fewest "downstream" interim appointments within the school. For example, selecting an associate dean for academic affairs as interim dean, may result in a department chair being appointed as interim associate dean, with the resulting need for an interim department chair. Multiple interims serving simultaneously within a school is generally not desirable in the experience of the authors, especially given the reality of longer term interim appointments in the current environment; (3) An individual who is a convener, negotiator, visionary, and collaborator. While the institution may be tempted to select someone with the most exemplary academic record as interim dean, the real need is for a leader who possesses these qualities and attributes.

Institutions should be mindful that an interim dean who is in the position for a year or longer will have tremendous influence over every aspect of the pharmacy program. Gone are the days of an interim dean being able to merely keep the ship afloat while warming the captain's seat until a permanent dean is selected. The competitive nature of pharmacy academia in terms of student recruitment, accreditation requirements, faculty recruitment and retention, and alumni support requires an active and engaged interim dean who can help move the school's and institution's existing priorities forward.

Institutions also need to anticipate that service in the role of an interim dean will likely launch the appointed individual into priority recruitment by other schools of pharmacy for permanent dean positions. Institutions should not avoid placing their best people in the interim dean role. It is a compliment for both the individual and the institution that others see the value in an interim dean's leadership. Notwithstanding, this may mean that an additional vacancy may soon result after filling the permanent dean position.

Appointment of an interim dean can be valuable to the institution. The interim appointment enables an individual to gain new experience and perspective, which can be beneficial to the institution whether the interim becomes a permanent dean or returns to his or her prior position. Upper administration may not be familiar with the talents and capabilities of the interim dean, so having that individual in the position allows them to evaluate the person for the permanent position. Hiring an inexperienced dean who later decides that the position or institution is not the "right fit" has unpleasant consequences for the institution, as well as for the individual and school. Also, when a beloved dean departs, an interim dean can assist the school in weathering the grieving and adjustment period and help to celebrate the outgoing dean's accomplishments. If the institution is open to collaboration with the school during the search, the interim period allows for school members to step back and assess what they need in the next leader.

Challenges will exist for the interim dean, whether or not the individual is planning to apply for the permanent dean position, such as moving school initiatives forward while keeping options open for a new dean who may want to proceed in a different direction. It takes a skilled navigator to chart a course for the permanent dean to transition into as easily as possible, take on new duties, oversee and/or transition the responsibilities of the interim's previous position, and manage the inevitable awkwardness if the interim dean is considering applying for the permanent position. Few interim deans have the luxury of maintaining the status quo. This can be particularly challenging if there is no agreement by the university administration and/or faculty members on what can and should be completed during the interim appointment and what should be delayed until a new dean is appointed.

In addition to the challenge of determining which initiatives to advance and which to delay, an interim dean is also expected to help prepare the school, community, and other stakeholders for a new dean. Determining which stakeholders the new dean will need to meet with upon arrival, reminding others that a new dean will be coming who will need input on decisions, and documenting conversations, actions, etc., all promote a smooth transition for the permanent dean.

The interim dean's responsibilities will require extensive commitment to areas that may not have been 


\section{American Journal of Pharmaceutical Education 2016; 80 (7) Article 112.}

experienced previously including university-wide enrollment goals, legal consults and responses, and financial constraints. Some aspects will be easier because of the interim dean's familiarity with the institution, program, and stakeholders, but there may still be factors outside the interim's previous position responsibilities. It will be important for the administration, faculty members, and staff to understand that the interim dean has new duties and may not step into the role and perform as a virtuoso in all areas.

Another challenge for an interim dean is the degree to which one is asked to wear an "old hat" while also managing a new role. Even in cases where an interim appointment creates another interim appointment (eg, a department chair becoming interim dean, who subsequently is replaced by an interim chair), the interim dean often finds he or she is spending a significant amount of time mentoring the other interim in his or her new role, while at the same time learning about the interim dean role. While the other interim may be capable, the interim dean should plan for time to answer questions or to track activities. We would recommend the use of dashboards or tracking forms to keep multiple priorities advancing. The interim dean is also likely to oversee the work of the previous position to create a smooth re-entry if he or she moves back into the previous role at the end of the interim appointment.

Faculty members, staff, and other administrators (especially those from outside the pharmacy program) may continue to approach the interim dean to directly address matters associated with previous responsibilities. The reality is that most organizations will find themselves operating in a "minus one" capacity, with two people essentially doing the work of three until a permanent dean begins.

In terms of applying for dean, interim deans may feel conflicted. The interim dean walks a fine line between needing to make changes and not making waves as a candidate. Each day may feel like a mini-job interview for the position and will present questions. "If I apply, what happens if I don't obtain the position?" "Can I go back to my old position and be fulfilled after serving at the dean's level?" "Will I be able to support the individual who is selected as the dean?" "Should I consider other positions at other institutions?"

Because a preference often exists within the academy that an external dean be appointed, individuals may not feel valued for their knowledge, institutional wisdom, experience, and loyalty that they have shown to their institution. They may not feel that they would represent the "preferred" candidate profile. Faculty members, students, alumni, and other stakeholders often expect an interim dean to apply for dean and believe that he or she would be a good fit as the program's next leader. If that is the case, colleagues should encourage the individual to apply.

A subset of interim deans are acting deans, who are appointed to their posts to essentially "cover" for a dean who is temporarily not able to serve in their position but plans to return at some point. Acting dean positions can be for relatively short, defined terms (eg, when the dean goes on a medical or other type of leave), or for longer, undefined terms (eg, when the dean is asked to fill an acting or interim role in another area of the university). In addition to factors already mentioned, acting deans generally have access to the person whose place they are taking. This can be helpful in gaining the knowledge and context that otherwise would not be available to an interim dean. On the other hand, it is clear that an acting dean's service is temporary (even if the length of the term is undefined) and that at some point the dean will return to the role. Acting deans will have opportunities to effectively manage their schools, but their ability to truly lead is limited.

While there are challenges associated with the interim dean role, there are also opportunities. Interim deans become familiar with the role of dean and whether it is one they wish to pursue on a permanent basis. Interim deans gain perspective on the institution, which can help them become more effective and engaged in the previous position. Furthermore, they can gain satisfaction from assisting a new permanent dean transition into the permanent role.

School of pharmacy faculty members and administrators may gain some sense of the responsibilities of a dean from observation. However, many aspects of the position must be experienced before they can truly be understood or appreciated. As an example, the interim dean quickly learns that the deanship can isolate one from peers because of confidentiality expectations for faculty and student conversations and decisions. When a closeddoor discussion concludes, the interim dean steps through an open door to positively lead, promote, and guide the school. Being able to serve as an interim dean gives one a chance to gain that experience before making a commitment to seek the position on a permanent basis.

Not only does the interim dean role give individuals opportunities to lead their programs, it also enables them to work with other deans and administrators at their universities, as well as to take on leadership roles within the profession itself. These experiences can lead to broader perspectives and increased effectiveness as one moves back into the previous position or into other career destinations. Interim deans, through their leadership and management of their programs, can help position their program to attract a larger pool of qualified applicants. 


\section{American Journal of Pharmaceutical Education 2016; 80 (7) Article 112.}

Activities that deans can, and often must, do, regardless of whether interim, acting, or permanent dean, include managing day-to-day operations of the school, addressing student and faculty matters, assuring financial stability, and maintaining (or even obtaining) the program's accreditation status. On the other hand, there are limits to what an interim dean can or should do prior to the permanent dean arriving. Interim deans generally are not expected to foster significant shifts in program goals and objectives or to initiate multiple major initiatives in schools already stressed by uncertainty.

Interim deans must manage and communicate expectations, particularly of what they are and are not expected to accomplish. People considering taking on interim dean roles should have a frank discussion with the provost and other administrators to delineate these expectations. Once outlined, expectations should be broadly communicated to faculty members and staff, students, alumni and friends, other leaders in the university, and external partners and constituencies.

Many scenarios are possible when a dean resigns, retires, or accepts another position, and an interim dean is appointed. The interim dean may be selected as dean to yield continuing momentum for the school. The interim dean who serves as acting dean may know that he or she will serve until the dean returns from a temporary appointment in upper administration. The interim dean may serve knowing that he or she will not apply for the deanship because of pre-existing commitments or personal circumstances, or may apply for dean but not be selected.

The authors have experienced all of these scenarios. Except in the first example when an interim dean is selected to become dean, the interim dean is, in a sense, "demoted" at some point. A former interim dean can be a strong mentor and ally for an incoming dean if given the opportunity. The interim dean who returns to a previous position may encounter unexpected changes in perceptions and familiarity among faculty members and staff. The interim dean not selected to become dean must self-assess whether he or she should seek a new opportunity outside the institution or within the school or university.

Those who do not become dean may experience a withdrawal of sorts after the interim dean appointment expires. It can be to shift from knowing everything about a school, being fully involved with university leadership, experiencing significant events such as the White Coat Ceremony and graduation as dean, to a former position, which may feel less impactful or prestigious, or carry less authority. While this could be considered stepping down as interim dean, it should be viewed that someone stepped up to serve in the school's time of need.

A former interim dean can still be effective within the existing institution. Honest conversations can yield new goals and/or new opportunities that one can use the leadership experience as interim dean to achieve. Despite being potentially uncertain about the destiny of the school, an individual who has served as interim dean should know that upper administration and the school community recognize his or her fitness to serve and can take advantage of the special connection to students and faculty members acquired during the interim period.

Except for title, there is no such thing as an interim dean. The individual must be committed on behalf of students, faculty members, staff, stakeholders, and the institution for however long the interim dean appointment lasts. Understanding the challenges but also the potential opportunities can help the institution and the interim dean to sail smoothly until the permanent dean assumes command.

\section{REFERENCE}

1. Draugalis JR, Plaza CM. A 20-year perspective on preparation strategies and career planning of pharmacy deans. Am J Pharm Educ. 2010;74(9):Article 162. 